\title{
Testicular antispermatogenic antibodies in obstructive azoospermia
}

\author{
H. Abdel Aal, A. Abdel Hafiz, O. Kandil and H. El Tonsy \\ Departments of Venereology, Clinical Pathology, and Obstetrics and Gynaecology, \\ Al Hussein Hospital, Al Azhar University, Cairo, Egypt
}

High titres of antisperm antibodies have been found in the sera of patients suffering from obstruction in the sperm passages (Shulman, 1971; Abdel Aal, El Atribi, Abdel Hafiz \& Aidaros, 1975). The presence of antibodies in the interstitial spaces and in damaged basement membranes in the testicular tissue of infertile men was reported by Isidori, Dondero \& Garufi (1968) and Isidori, Dondero \& Lombardo (1970), who used an immunofluorescence technique, and confirmed by Le Lorier, Salat \& Rotman (1970). The incidence of immunological lesions in the testes of infertile men was about $22.3 \%$ (Le Lorier et al., 1970; Isidori et al., 1973). In normal men, testicular immunoglobulins mainly occur in the interstitial cells and their concentration in the germinal cells is very low (Abdel Aal, Abdel Hafiz, Kandil \& El Tonsy, 1976). The aim of the present work was to study the pattern and concentration of testicular immunoglobulins in patients with obstructive azoospermia.

\section{Materials and methods}

Anti-human gamma globulin antiserum, raised in rabbits, was purchased freeze-dried (Miles Laboratories, Inc., Kankakee, Illinois, U.S.A.) and conjugated to horse radish peroxidase (Sigma type VI) by the method of Nakane \& Pierce (1966). The potency of the antiserum was $5.5 \mathrm{mg}$ antibody/ $\mathrm{ml}$. The contents of two vials of antiserum (55 mg antibody) and $55 \mathrm{mg}$ peroxidase were dissolved in $2.1 \mathrm{ml} 0.5 \mathrm{M}$ cold carbonate buffer $(\mathrm{pH} 10)$ and $0.27 \mathrm{ml} 0.5 \% p, p^{\prime}$-difluoro- $m$ - $m^{\prime}$-dinitrodiphenyl sulphone in acetone was added. The mixture was agitated for $6 \mathrm{hr}$ at $4^{\circ} \mathrm{C}$ and was dialysed against phosphate-buffered saline (PBS) overnight. A precipitate was removed by centrifugation. After precipitation with an equal volume of saturated ammonium sulphate in distilled water, the precipitate was collected, washed twice in a $50 \%$ solution of saturated ammonium sulphate in PBS, and dissolved in and dialysed against PBS. The conjugate was absorbed with liver powder.

Testicular biopsies were surgically obtained from 9 patients who were admitted to Al-Hussein Hospital for infertility investigations. All the patients had obstructive azoospermia which followed bilateral epididymo-orchitis. The testicular tissue was fixed in Bouin's fluid, and embedded in paraffin wax. For each biopsy, three slides of $6 \mu \mathrm{m}$ sections were prepared. One slide was stained with haematoxylin and eosin; the second (test) was washed with PBS and incubated with the enzyme-labelled antiserum for $30 \mathrm{~min}$. The third (control) slide was washed in PBS, and incubated with an unlabelled portion of the antiserum for $30 \mathrm{~min}$. After incubation, test and control sections were washed in three changes of PBS.

The method of Graham \& Karnovsky (1966) was used to determine the sites of localization of testicular immunoglobulins (test sections). The sections were incubated at room temperature for

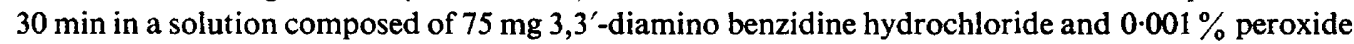
in $100 \mathrm{ml} 0.05 \mathrm{M}$-tris- $\mathrm{HCl}$ buffer, $\mathrm{pH} \mathrm{7.6}$. The sections were washed in tris buffer and osmicated in $2 \% \mathrm{OsO}_{4}$ in distilled water, washed, dehydrated and cleared in xylol and mounted. The peroxidase enzyme label produced a light to dark-brown colour according to the concentration of the antibodies. The stain was considered specific in the test section when it was reduced in density in the corresponding control section. 


\section{Results and discussion}

Six of the nine cases exhibited variable degrees of maturation arrest, mainly at the spermatid stage (PI. 1, Fig. 1). Disorganization, sloughing of immature cells and Sertoli cell vacuolization were also seen in some specimens. In five of these specimens, the germinal cells contained very high concentrations of immunoglobulins (Pl. 1, Fig. 2). All the control sections for these specimens (Pl. 1, Fig. 3) showed that the stain was specific for immunoglobulins.

The abnormal findings in the present study can reasonably be attributed to the presence of cellbound antibodies in the germinal cells, since no immunoglobulins were found in the germinal cells of normal men (Abdel Aal et al., 1975). The maturation arrest associated with the presence of immunoglobulins may be due to the cell-bound antibodies being antispermatogenic. The mechanism of production of such antispermatogenic testicular antibodies may be autoimmunization against spermatozoa extravasating behind the obstruction. Epididymo-orchitis, which is usually the cause of obstruction, can enhance the immune response and produce serum antisperm antibodies. A cellular type of immunity seems to be needed for cell-bound antibodies to pass the blood-testis barrier and become fixed to the germinal cells. Raff (1973) has explained how T and B lymphocytes can interact in humoral and cell-mediated immunity and how each type of immune response can potentiate the action of the other. Shulman (1971) has stated that sperm autoantibodies often occur in patients who have normal testicular histology, but the present findings suggest that cell-mediated immunity is the more important immune response which affects the testicular histology.

We thank Dr K. A. Laurence of the Population Council, New York, for valuable discussion and technical advice.

\section{References}

Abdel Aal, H., El Atribi, A., Abdel Hafiz, A. \& Aidaros, M. (1975) Azoospermia in bilharziasis and the presence of sperm antibodies. J. Reprod. Fert. 42, 403-406.

Abdel Aal, H., Abdel Hafiz, A., Kandil, O. \& EL Tonsy, H. (1976) Immuno-histochemical localization of human testicular immunoglobulins. Al Azhar med. J. (in press)

Graham, R.C. \& Karnovsky, M.J. (1966) The early stages of absorption of injected horseradish peroxidase in the proximal tubules of mouse kidney: ultrastructural cytochemistry by a new technique. $J$. Histochem. Cytochem. 14, 291-302.

IsIDORI, A., Dondero, F. \& Garufi, L.A. (1968) Rilievi di immunopathologia nel testicolo umano. Folia endocr. 21, 271-285.

IsIDORI, A., DONDERo, F. \& LOMBARDo, D. (1970) Anti- testicular immunity. Role of basement membrane. Experientia 26, 1375-1376.

IstDori, A., Dondero, F. \& Lombardo, D. (1973) Autoimmunization in male infertility. In Immunology of Reproduction, pp. 94-101. Eds K. Bratanov, R. G. Edwards, V. H. Vulcanov, V. Dikov \& B. Somlev. Bulg. Acad. Sci. Press, Sofia.

Le Lorier, G., Salat, J. \& Rotman, J. (1970) Problèmes posés par l'auto-immunisation dans la sterilité masculine. Gynéc. Obstét. 69, 23-34.

NAKANe, P.K. \& Pierce, G.B. (1966) Enzyme-labelled antibodies: preparation and application for the localization of antigens. J. Histochem. Cytochem. 14, 929-931.

RAFF, M.C. (1973) T \& B lymphocytes and immune responses. Nature, Lond. 242, 19-23.

Shulman, S. (1971) Immunity and infertility: a review. Contraception 4, 135-154.

Received 30 September 1975 


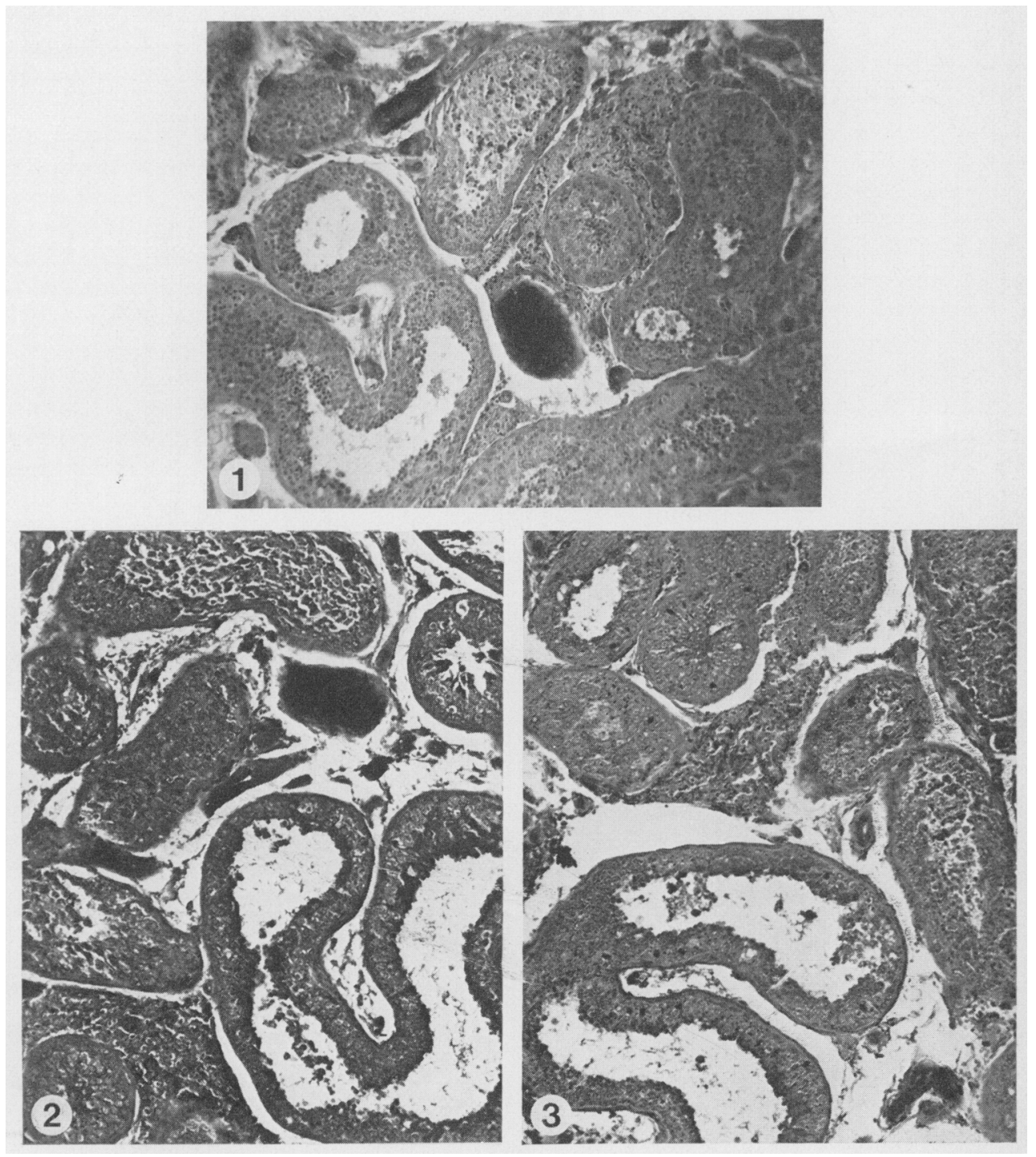

Fig. 1. Section of test is from a man with obstructive azoospermia showing maturation arrest. H \& E, $\times 73$.

Fig. 2. Testicular section from the same patient as Fig. 1 showing the high concentrations of peroxidaselabelled antihuman gamma-globulins in the germinal cells. $\times 80$.

Fig. 3. Testicular section from the same patient as Fig. I showing the lack of staining by peroxidase-labelled antihuman gamma-globulins after incubation with unlabelled antiserum. $\times 80$. 